\title{
Review \\ Endothelial Glycocalyx as a Regulator of Fibrotic Processes
}

\author{
Valentina Masola ${ }^{1,2}{ }^{\mathbb{D}}$, Gianluigi Zaza ${ }^{2} \mathbb{D}$, Arduino Arduini ${ }^{3}$, Maurizio Onisto ${ }^{1, *(\mathbb{D})}$ and Giovanni Gambaro ${ }^{2, * \mathbb{D}}$ \\ 1 Department of Biomedical Sciences, University of Padova, Viale G. Colombo 3, 35121 Padova, Italy; \\ valentina.masola@unipd.it \\ 2 Division of Nephrology and Dialysis, Department of Medicine, Piazzale A. Stefani 1, 37126 Verona, Italy; \\ gianluigi.zaza@univr.it \\ 3 R\&D Department, CoreQuest Sagl, Via Cantonale 18, 6928 Manno, Switzerland; a.arduini@corequest.ch \\ * Correspondence: maurizio.onisto@unipd.it (M.O.); giovanni.gambaro@univr.it (G.G.)
}

check for updates

Citation: Masola, V.; Zaza, G.;

Arduini, A.; Onisto, M.; Gambaro, G. Endothelial Glycocalyx as a Regulator of Fibrotic Processes. Int. J. Mol. Sci. 2021, 22, 2996. https://doi.org/ $10.3390 /$ ijms 22062996

Academic Editor:

Hironobu Yamashita

Received: 1 February 2021

Accepted: 11 March 2021

Published: 15 March 2021

Publisher's Note: MDPI stays neutral with regard to jurisdictional claims in published maps and institutional affiliations.

Copyright: (C) 2021 by the authors Licensee MDPI, Basel, Switzerland. This article is an open access article distributed under the terms and conditions of the Creative Commons Attribution (CC BY) license (https:// creativecommons.org/licenses/by/ $4.0 /)$.

\begin{abstract}
The endothelial glycocalyx, the gel layer covering the endothelium, is composed of glycosaminoglycans, proteoglycans, and adsorbed plasma proteins. This structure modulates vessels' mechanotransduction, vascular permeability, and leukocyte adhesion. Thus, it regulates several physiological and pathological events. In the present review, we described the mechanisms that disturb glycocalyx stability such as reactive oxygen species, matrix metalloproteinases, and heparanase. We then focused our attention on the role of glycocalyx degradation in the induction of profibrotic events and on the possible pharmacological strategies to preserve this delicate structure.
\end{abstract}

Keywords: endothelium; glycocalyx; fibrosis

\section{Introduction}

The endothelium was once only known as the cellular internal monolayer of blood and lymphatic vessels, but now it is also recognized as a dynamic organ. First of all, endothelial cell phenotype is different in different organs and districts, and this reflects specific functions [1]. For instance, in the kidney, endothelial cells of the large vessels are a continuous layer kept together by intercellular junctions, whereas glomerular endothelial cells and endothelial cells of peritubular capillaries are highly fenestrated [2]. Endothelial cells are covered by a gelatinous layer called the "glycocalyx", which represents an important element of the vascular barrier [3].

In the last few years, it has appeared that (1) a great deal of endothelial functions are modulated and mediated by the glycocalyx, (2) the integral endothelial surface layer is an important element in tissue homeostasis, and (3) alterations of this structure are involved in several pathophysiological conditions: sepsis as well as chronic cardiovascular, renal, and metabolic diseases [4-7].

In this review, we will describe the composition and function of endothelial glycocalyx together with the mechanisms responsible for its degradation. We will also focus on the recent findings as to the role of the endothelial glycocalyx in the modulation of renal fibrosis. Finally, we will discuss the present and possible future strategies aimed at preserving this delicate structure.

\section{Endothelial Glycocalyx Structure and Functions}

The glycocalyx is synthesized by vascular endothelial cells and expressed on the endothelial cell surface [8], and it is mainly composed of membrane-binding proteoglycans (mainly syndecans 1, 2, and 4 and glypican 1), glycosaminoglycan (GAG) side-chains conjugated with the core protein of the proteoglycans, hyaluronan, glycoproteins, and adsorbed plasma proteins (such as albumin and antithrombin) [9].

Proteoglycans are a group of molecules composed of a core protein to which several GAGs are attached. GAGs are negatively charged unbranched polysaccharide chains made up of the repetition of disaccharide units. Depending on their core disaccharide units, 
GAGs are classified in heparin/heparan sulfate, chondroitin sulfate, dermatan sulfate, and keratan sulfate [10]. Since GAGs have sulfated groups, they are negatively charged, and this gives them the capacity to bind several growth factors and cytokines, thus protecting them from degradation [11]. Moreover, they create a gradient necessary for fluid transit and renal blood filtration [12,13]. Hyaluronan (a nonsulfated GAG) is found mainly in the luminal part of the glycocalyx, and it is not attached to a core protein but binds to surface receptors (e.g., CD44) [14].

Syndecans are central elements in endothelial cell homeostasis. Their interaction with ligands modulates endothelial cell growth and behavior [15]. Glypicans are important regulators of angiogenesis and coagulation [16,17]. The three groups of cell glycoproteins present in the endothelial glycocalyx are the selectin family, the integrin family, and the immunoglobulin superfamily [8]. E-selectin and P-selectin are both expressed by endothelial cells with different mechanisms and both modulate leukocyte-endothelial cell interactions [18-20]. Integrins are transmembrane receptors [21] that mediate platelet-endothelial cell interactions [22] and facilitate cell-extracellular matrix (ECM) adhesion [23]. The principal elements of immunoglobulin glycoproteins are intercellular adhesion molecules 1 and 2 (ICAM-1 and -2), vascular cell adhesion molecule 1 (VCAM-1), and platelet/endothelial cell adhesion molecule 1 (PECAM-1), and they regulate the binding of leukocytes and platelet endothelium [24].

The thickness of the glycocalyx was reported to be $4-500 \mathrm{~nm}$, which depends on the measurement technique, and it was observed that there is a dense inner matrix layer associated with membrane-attached glycoproteins and a less-dense outer layer composed mainly of GAGs and plasma proteins [25]. Thickness is also modulated by the balance between synthesis caused by endothelial cells, GAG depolymerization, and proteoglycan shedding. Globally, the endothelial glycocalyx is a structure in dynamic equilibrium with the components of the flowing blood [26-28]. Interestingly, it has been proved that cerebral endothelial glycocalyx thickness is not homogeneous among pial arteries, penetrating arteries, and capillaries. Glycocalyx thickness was not correlated with the vessel diameter, but it might reflect the functional heterogeneity of the vessel type [29].

The main functions of the glycocalyx are the control of vessel tone in response to shear stress, the regulation of the permeability, coagulation and complement system, as well as the regulation of endothelial-blood cell interaction.

Proteoglycans such as syndecans and glypicans, but also hyaluronic acid, are mechanotransducers of the shear forces to endothelial cells [30]. For instance, when the flow becomes multidirectional, there is a modification of plasma proteins, cations, and cationic amino acids associated with GAGs and this could aid in syndecan- 1 oligomerization and transduction of the signal via its intracellular domain, which is associated with linker molecules that connect them to the cytoskeleton [31]. The principal effects of shear stress are the alignment of endothelial cells in the shear direction (via mechanotransduction) and the production of nitric oxide (NO): a mediator that induces smooth muscle cell relaxation and, consequently, vasodilatation, and the reduction of shear stress [32].

The negatively charged endothelial glycocalyx represents an electrostatic barrier for plasma cells and proteins, like albumin. It also regulates permeability to water and small molecules and oxygen [12,33] and allows for the selective buffering of sodium ions [34]. It has been proved that enzymatic elimination of the majority of the endothelial glycocalyx modulates hydrostatic and oncotic pressure gradients between the lumen of the blood vessel and the interstitial space [35-37].

A functional glycocalyx represents an antithrombotic and anticoagulant surface as antithrombin III bound to GAGs modulate several coagulation factors [38] and GAGs interact with multiple complement elements of both: classic alternative and lectin pathways [39]. During inflammation, several cytokines activate the expression of tissue factors on endothelial cells. Tissue factor binds to and activates clotting factor VII, which via factor $X$, results in the generation of thrombin and conversion from fibrinogen to fibrin [40]. Thrombin can activate PAR1, which, in turn, induces the production of several cytokines 
and growth factors and causes platelet activation and aggregation. On endothelial cells, PAR1 activation rises endothelial permeability, and the von Willebrand factor (vWF) secretion from that participates in platelet recruitment. Platelets can also be activated by proinflammatory mediators and thus sustain fibrin formation [41,42].

One of the most important physiological roles of the glycocalyx is the recruitment of leukocytes to areas of infection with a multistep process: tethering, rolling, adhesion, and transmigration. Ordinarily, cell adhesion molecules on the endothelium, such as integrins and immunoglobulin glycoproteins, are hidden within the glycocalyx, but, once infection occurs, the glycocalyx is degraded by inflammatory mediators, which facilitate ligand-receptor interactions that promote the adhesion of leukocytes (Figure 1) [38].

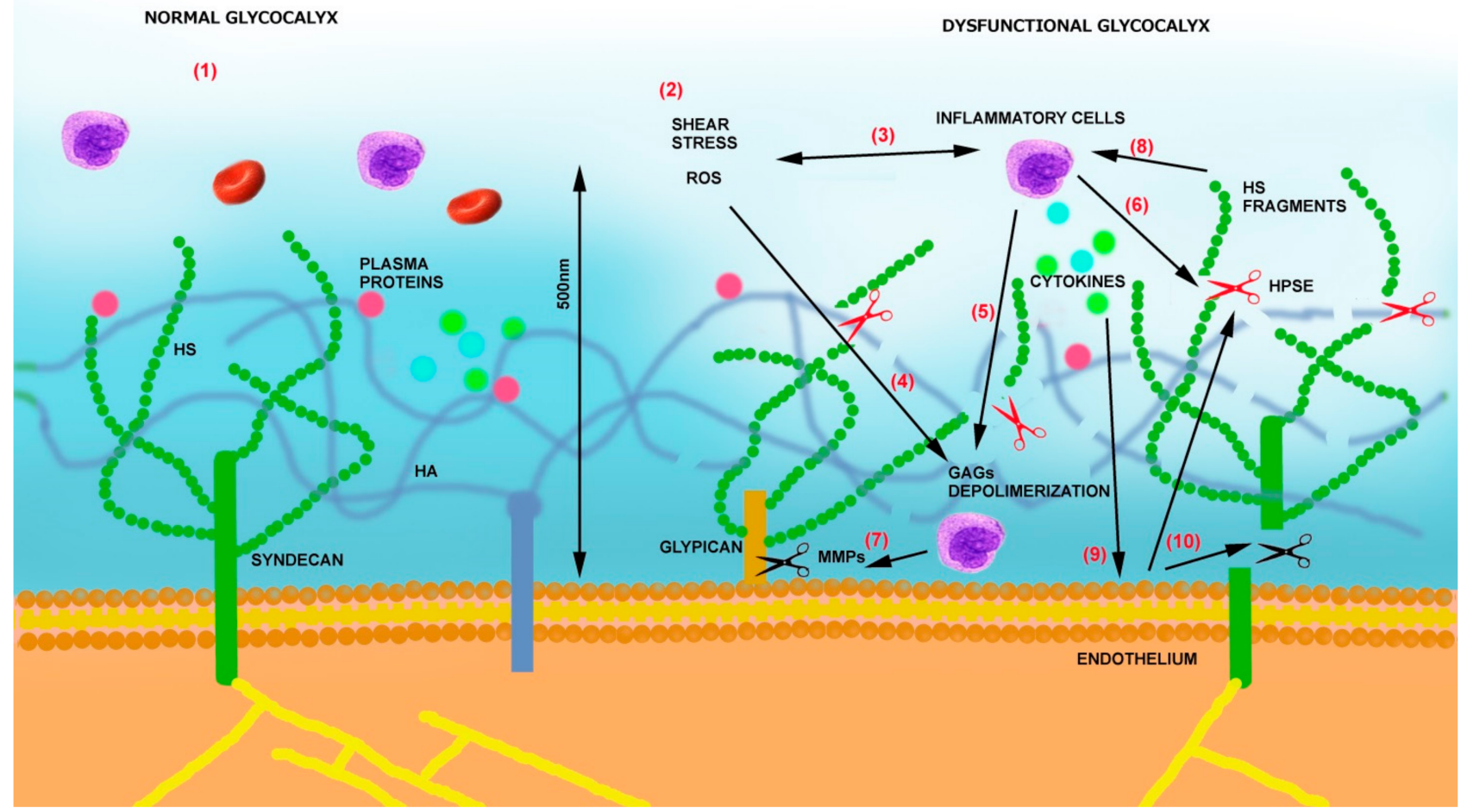

Figure 1. (1) Under physiological conditions, the glycocalyx represents a protective layer of proteoglycans (syndecans and glypicans), glycosaminoglycans (GAGs) (HS-heparan sulfate, HA—hyaluronic acid), and adsorbed plasma proteins. (2) In pathological situations such as atherosclerosis, ischemia, and diabetes, a series of stimuli impact glycocalyx integrity. (3) ROS and shear stress recruit activated inflammatory cells, and inflammatory cells release additional ROS. (4) ROS participates in GAG depolymerization, which aids in (5) leukocyte activation and macrophage extravasation. Activated inflammatory cells release (6) HPSE (red scissors) and (7) matrix metalloproteinases (MMPs) (black scissors). MMPs shed the protein extra-domains of proteoglycans, and HPSE cleaves HS chains. (8) Soluble syndecans and HS fragments additionally activate inflammatory cells (9), which release cytokines. (10) Cytokines and growth factors activate endothelial cells to produce MMPs and HPSE, fueling the system.

\section{Mechanisms of Endothelial Glycocalyx Damage}

The mediators of glycocalyx degradation are copious, and some of them are interconnected, thus creating a vicious cycle: reactive oxygen/nitrogen species (ROS/RNS), matrix metalloproteinases (MMPs), hyaluronidase, and heparanase.

ROS and RNS are directly able to destroy GAGs; specifically, they induce modification in sugars and aid their hydrolytic cleavage $[43,44]$. Interestingly, hyaluronic acid (HA) is highly sensitive to chemical insults resulting in the generation of low-molecular-weight HA [45]. These species, in turn, activate a proinflammatory state, resulting in increased ROS/RNS production [46]. 
MMPs are a family of zinc-dependent endopeptidases that degrade extracellular matrix components (collagen, elastin, etc.). In the vasculature, MMPs are mainly expressed by inflammatory cells and, after specific stimuli, by endothelial and smooth muscle cells $[47,48]$. Their expression is regulated by ROS, cytokines, shear stress, and hypoxia [38]. In the glycocalyx, MMPs cleave the extracellular domains of syndecans. Syndecan- 1 is shed by MMP-2, MMP-9, MT1-MMP, and ADAM-17 [39]. Syndecan-4 is shed by MMP-9 in a TNF- $\alpha-$ dependent manner [49]. MMPs are also able to cleave chondroitin sulfate [50].

Heparanase is an endo- $\beta$-D-glucuronidase, which cuts the heparan sulfate (HS) chains at the level of a limited number of specific intrachain sites, generating fragments of about 5-7 kDa [51]. Upregulation of heparanase expression in the vascular endothelium at the site of inflammation has been reported in multiple organ systems and promotes inflammatory responses [52]. Heparanase expression is upregulated in endothelial cells by several factors: ROS [53], inflammatory cytokines [54], high glucose [55], and advanced glycosylation products [56]. In the vascular district, heparanase is also released by inflammatory cells and platelet [57].

Heparanase can modulate glycocalyx damage in a manifold manner.

(1) By degrading HS, it modulates the interaction of endothelial cells with blood cells [58], regulates vascular permeability [59], and makes adhesion molecules on endothelium more accessible to circulating inflammatory cells [60].

(2) By releasing proinflammatory cytokines and chemokines bound to GAGs, it sustains inflammation, oxidative stress, and additional glycocalyx damage [61].

(3) Heparanase is also able to sustain inflammation by activating Toll-like receptors (TLRs) on macrophages via heparan sulfate fragments, leading to the activation of nuclear factor- $\mathrm{kB}$ (NF- $\mathrm{kB}$ ), which results in the expression of additional inflammatory cytokines (TNF- $\alpha$, IL-1 $\beta$, and IL-8) [62]. The same cytokines can then sustain heparanase expression on endothelial cells [54] as well as the production of MMPs [63] and ROS.

(4) Heparanase also contributes to glycocalyx damage, thus increasing their procoagulant state by increasing tissue factor (TF) and modulating tissue factor pathway inhibitor (TFPI) [64].

(5) Lastly, the glypicans can also undergo shedding by phospholipase-D and notum (Figure 1) [65].

\section{Glycocalyx Dysfunction Conditions}

Pathological damage of the glycocalyx occurs in response to mechanical cellular stress, endotoxins, inflammatory mediators, atrial natriuretic peptide, ischemia/reperfusion injury, free oxygen radicals, and hyperglycemia, as well as the novel coronavirus disease 2019 (COVID-19) [49,66]. Degradation of the glycocalyx results in the shedding of some of its components in the blood flow (hyaluronic acid, heparan sulfate, syndecan-1 and 4, and glypicans), and often they correlate with the severity of particular diseases [50,67].

Glycocalyx degradation happens in infective (sepsis) and noninfective (trauma) inflammation [68], and in these settings, tissue necrosis factor-a (TNF-a) has a central role [69]. It exerts its role via heparanase activation and MMP9 upregulation [63,70]. Sepsis causes glycocalyx degradation but also delays its regeneration [71]. The breakdown of the endothelial glycocalyx stimulates macrophage recruitment and macrophage phenotype alterations [72,73] as well as leukocyte adhesion and focal vascular inflammation [74].

Collecting proof from in vitro and in vivo studies shows that hemorrhagic shock induces endothelial glycocalyx shedding and endothelial injury, accompanied by disturbed junctional integrity [75,76]. During ischemia/reperfusion (I/R) injury, it is damaged both during the hypoxic phase but also by the restoration of the blood supply (reperfusion). Endothelial cells after ischemia/reperfusion become swollen and detached from the basement membrane. Increased release of histamine and cathepsin, as well as oxygen free radicals and heparanase, may account for glycocalyx damage $[77,78]$. It has been proved that in 
patients undergoing major vascular surgery with global or regional ischemia, components of the glycocalyx, such as heparan sulfate and syndecan-1, are released into the plasma [79].

There is evidence that diabetes disturbs the vasculature globally, and alterations of the endothelial glycocalyx happen early in the onset of the disease [80]. It has been proved that acute hyperglycemia increases glycocalyx degradation and vascular barrier instability [81] confirmed also by in vitro studies [82].

The new coronavirus disease 2019 (COVID-19) caused by severe acute respiratory syndrome coronavirus 2 (SARS-CoV-2) in patients induces not only pulmonary disease, eventually culminating in acute respiratory distress syndrome (ARDS), but also produces multiple systemic effects, including acute kidney injury (AKI), acute cardiac injury, coagulopathy, thromboembolic complications, including stroke and pulmonary embolism, and circulatory shock [83]. Vascular endothelial damage has been identified as a common feature of high-risk patients prone to severe COVID-19, and several studies have shown that endothelial glycocalyx is seriously damaged during COVID-19, as proved by the increased shedding of syndecan- 1 and hyaluronic acid and increased levels of heparanase $[66,84]$.

\section{Role of Glycocalyx Dysfunction in Fibrosis}

Some recent findings indicate that mechanisms involved in endothelial glycocalyx dysfunction may participate in organ fibrosis, especially in renal fibrosis. Renal fibrosis is the final common outcome of practically all renal diseases causing chronic kidney disease (CKD). The main macroscopic characteristics of renal fibrosis are glomerulosclerosis, tubulointerstitial accumulation of extracellular matrix, inflammatory infiltration, tubular atrophy, capillary loss, and podocyte depletion. These events are caused by several biological events, including mesangial and fibroblast activation, monocyte/macrophage and T-cell infiltration, and cell apoptosis, which result in irreversible organ damage [85]. Activated myofibroblasts are the sources of extracellular matrix accumulation and they originate from several sources: interstitial renal fibroblasts, interstitial perivascular cells called pericytes, fibrocytes, tubular epithelial cells, and endothelial cells [86].

As described above, heparanase is an active player in glycocalyx remodeling, and the same agents that disrupt glycocalyx represent an element of damage and triggers renal fibrosis. Heparanase plasmatic levels are upregulated in chronic kidney disease patients [87], and several works have proved that heparanase is a central player in regulating the development and progression of renal fibrosis by modulating the epithelialto-mesenchymal transition (EMT) of proximal tubular cells in diabetic conditions and after ischemia/reperfusion injury (I/R) [88-91]. We can therefore speculate that increased plasmatic heparanase levels can then sustain local fibrosis in damaged areas.

One of the actions of heparanase is the mobilization of cytokines and growth factors from the GAGs of the glycocalyx. Among them, TGF- $\beta$ and FGF-2 are crucial elements that prompt fibrosis, and it has also been proved that heparanase sustains their induced EMT in the kidney $[92,93]$. Specifically, heparanase is necessary to maintain a rapid TGF- $\beta$ effect and sustain its autocrine loop [92]. Heparanase is also necessary to activate FGF-2 signaling and maintain the autocrine loop by regulating MMP-dependent syndecan-1 shedding [93].

As described above, glycocalyx degradation is a crucial step for inflammatory cell recruitment, and heparanase is necessary for macrophage infiltration in diabetic nephropathy [91] and I/R injury [93]. It has been proved that heparanase polarizes macrophages toward an M1 proinflammatory and profibrotic phenotype in I/R injured kidney, and then it regulates the cross-talk between macrophages and tubular epithelial cells, which undergo EMT [94]. The recruitment of M1 macrophages then increases the production of profibrotic cytokines [94], which participate in the development of CKD and organ fibrosis. A recent study proved, in a mouse model, that heparanase inhibition prevented the development of chronic fibrosis in a model of I/R injury [88]. Overall, the present findings prove that heparanase, independently of the underlying nephropathy, regulates the development of fibrosis in chronic kidney disease modulating EMT and inflammation. 
In the kidney, endothelial glycocalyx damage increased the production of vasoconstrictor agents [95]. Endothelin-1 (ET-1) is a potent endothelial-cell-derived vasoconstrictor. It is triggered by multiple stimuli such as ROS and inflammatory cytokines [96] and is released upon endothelial activation and activates two G-protein-coupled receptors, endothelin receptor type A (ETRA) and endothelin receptor type B (ETRB). Together, these receptors induce a variety of intracellular signaling cascades, resulting in vasoconstriction, proliferation, inflammation, extracellular matrix production, and fibrosis [97,98]. Recent findings have proved a renal interaction between heparanase and ET-1. Firstly, it was observed that endothelin- 1 activates podocytes to release heparanase, thus causing damage to the glycocalyx, proteinuria, and renal failure [99]; secondly, it was observed that heparanase overexpression increases ET-1 levels after I/R renal injury [77], and heparanase inhibition reduces ET-1 expression [77,88] and its associated renal fibrosis [88]. This system, which leads to renal damage and fibrosis development, is also fueled by other agents, angiotensin II and aldosterone. Angiotensin II induces the production of ET-1 in podocytes and mesangial cells [95], increases heparanase expression, and, moreover, induces the production of aldosterone, which additionally increases heparanase expression [100].

An additional layer of evidence as to the involvement of heparanase in diabetic nephropathy is its levels observed in the urine of diabetic patients. Those (diabetics) who underwent kidney transplantation showed significantly lower urine heparanase levels compared to the ones who had not undergone a transplant [101]. Although it is known that glucose may regulate heparanase secretion [102], insulin seems to cooperate with glucose to promote heparanase secretion in HK-293 cells, though heparanase gene expression is inhibited by insulin in human aortic endothelial cells [103]. Moreover, heparanase per se has been shown to trigger the activation of the insulin receptor signaling pathway [104], leading to ERK activation [105], a well-known signaling pathway involved in EMT. Should this also occur in endothelial cells, a heparanase-insulin-dependent vicious cycle would further amplify/accelerate fibrotic processes. It should also be borne in mind that endothelial cells in insulin-resistant and/or diabetic subjects develop a selective insulin resistance whereby only the antiatherogenic IRS-PI3K-Akt arm responsible for NO production becomes resistant [106]. The other arm, the MAPK-ERK pathway, known to be proatherogenic, retains responsiveness to insulin. Thus, the selective loss of insulin action may further aid CVD.

Another capable linker between endothelial glycocalyx dysfunction and fibrosis is sirtuin-1 (SIRT1). Sirtuins (silent information regulator (SIRT)) are a group of NADdependent histone deacetylases that regulate chromatin silencing and transcriptional repression. Since they modulate several pathways, they are linked to cellular energy metabolism, mitochondrial biogenesis, stress response, apoptosis, inflammation, and also fibrosis [107]. The lack or reduction of SIRT1 impacts all the endothelial functions [106], but mice with endothelial deficiency of SIRT-1 develop tubulointerstitial fibrosis as well [108]. In this model, it has been described that SIRT-1 deficiency is associated with decreased MMP-14 levels [109]. It has also been documented that treatments with losartan, an angiotensin II receptor blocker, and hydrogen-rich water by increasing SIRT-1 reduce EMT and fibrosis in UUO mouse models [110,111].

It has been proved that depletion of SIRT1 increases TGF- $\beta 1$ activation, the acetylation of Smad3 [112], and that mice with endothelium-specific heterozygous TGF $\beta$ receptor II knockout (TGF $\beta$ RIIendo+/-) are also protected against tubulointerstitial fibrosis via the inhibition of endothelial-to-mesenchymal transition [113]. Recently, it has been proved that a possible link between dysfunctional endothelial cells and the activation of fibroblasts, supporting fibrosis, could derive from specific factors secreted by endothelial cells with low (or lacking) SIRT-1 levels [108]. It has been found that endothelial cells lacking SIRT-1, when treated with TGF- $\beta$, release increased levels of Jagged1, Dickkopf-related protein 3 (DKK3), and syndecan-4 [108]. Jagged1 is a ligand of the Notch pathway, and DKK3 is a putative ligand of the Wnt pathway. Both pathways are implicated in the development of fibrosis [114]. The increased expression of syndecan-4 in endothelial cells lacking SIRT- 1 is mediated via the NF- $\mathrm{kB}$ pathway. Normally, SIRT-1 deacetylates p65 and prevents its nuclear translo- 
cation [115], but when it is reduced, p65 increases the transcription of syndecan-4, which has NF-kB-response elements in its promoter regions [116]. The shedding and processing of heparan sulfate proteoglycan syndecan- 4 are mediated by ADAM-17 and heparanase, and both are under NF- $\mathrm{kB}$ regulation. Lastly, syndecan-4 ectodomain accumulation in the interstitium acts as a macrophage chemoattractant, increasing fibroblast activation and inducing renal interstitial fibrosis (Figure 2) [117].

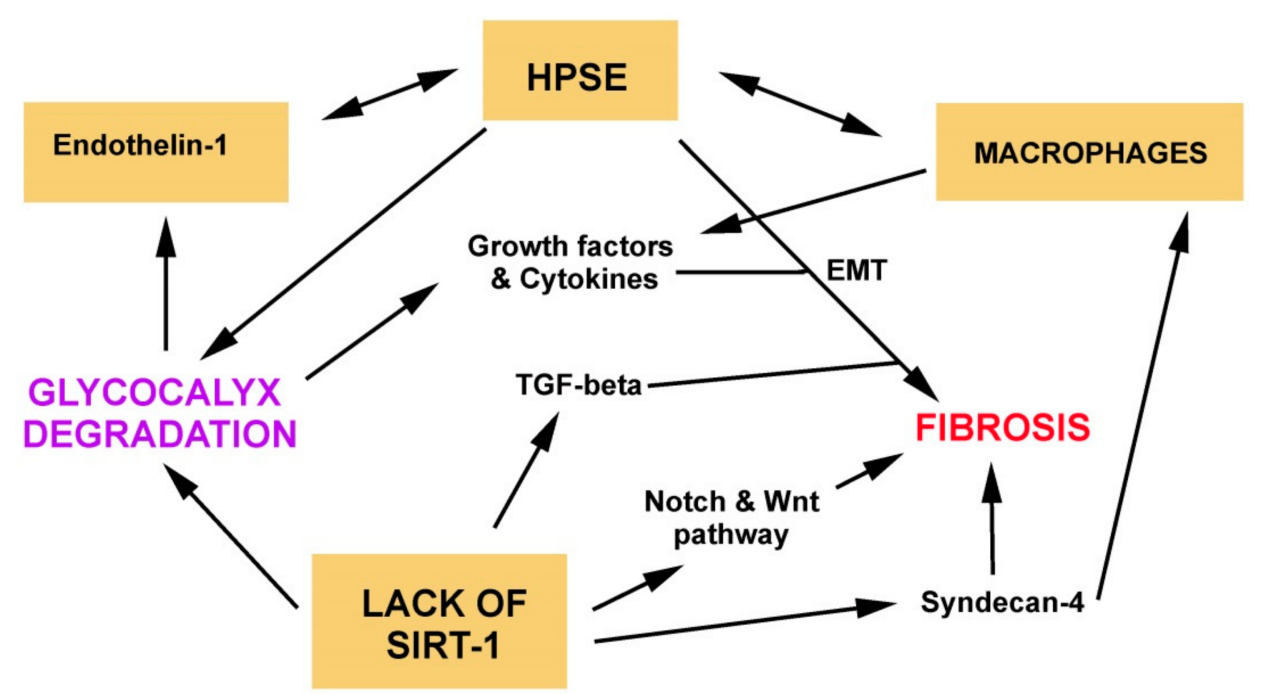

Figure 2. A series of noxa (ischemia/reperfusion (I/R), ROS, diabetes hyperinsulinemia, sepsis) increases heparanase production, which participates in glycocalyx degradation and the release of growth factors. Heparanase and these factors then sustain fibrosis via the activation of the EMT process. There is close interaction between macrophages and heparanase in the regulation of the fibrotic process. The production of heparanase is moreover sustained by a vicious loop with endothelin-1 released during glycocalyx degradation. In addition, the reduction of sirtuin- 1 increases TGF-beta signaling fueling fibrosis via EMT. The lack of sirtuin-1 also induces fibrosis through the activation of the Notch and Wnt signaling pathways and the release of syndecan-4, which acts as a chemoattractant.

\section{Therapeutic Strategies to Preserve Glycocalyx}

Since glycocalyx degradation affects the normal functions of endothelium but also influences several pathological processes such as inflammation and fibrosis, there is the necessity of therapeutic intervention to preserve its integrity and to restore its structure. Below, we will briefly show the available and promising strategies to achieve this goal.

- Resuscitation fluids (fresh frozen plasma, plasma albumin, and hydroxyethyl starch) may influence glycocalyx shedding [118].

- It has been proved that anesthetic sevoflurane attenuates glycocalyx degradation in guinea pig hearts in a myocardial I/R injury model [78].

- Glucocorticoid: hydrocortisone reduced coronary resistance, vascular permeability, tissue edema, the release of lactate, uric acid, purines, and histamine, which were accompanied by severe degradation induced by TNF- $\alpha$ [119]. Dexamethasone suppressed the expression of MMPs and rescued the expression of ZO-1 and syndecan-1 in sepsis [120].

- Elevated levels of oxidative stress are present in the serum of CKD patients [121]; moreover, antioxidant elements such as ascorbic acid are reduced, limiting NO bioactivity [122]. Some strategies aimed at reducing oxidative stress have been tested. In a rat model of angiotensin-II-induced hypertension, the administration of green tea extract restored endothelium vasodilatation through ROS scavenging [123]. Additionally, the use of the antioxidant $\mathrm{N}$-acetylcysteine reduces oxidative stress in a hyperglycemic state and, by doing so, reduces endothelial activation [124]. 
- Heparin and heparinoids may act toward several mechanisms. Firstly, heparins, by binding to endothelial cells, participate in the reconstitution of the glycocalyx and recover its negative charge [125]. It has also been reported that heparins increase heparan sulfate production and sustain its sulfation pattern [126]. Secondly, heparins are able to control multiple inflammatory effects. Heparins are able to protect cells from ROS, and they bind complement, growth factors and cytokines (i.e., interferon- $\gamma$ and FGF-2), and P- and L-selectin (inhibiting leukocyte adhesion) [127]. Third, heparins protect endothelial cells from high-glucose damage by preventing the interaction of advanced glycosylation end products with their receptors [128], reducing membrane disruption and cell death [127]. Lastly, heparins are heparanase inhibitors, and thus they can modulate all the effects of this enzyme in direct glycocalyx degradation but also in inflammation and fibrosis [127]. Heparins are also able to bind and inhibit NF-kB [128] and thus regulate inflammatory cytokines but probably also the same heparanase and syndecan-4 expression involved in the development of fibrosis [88,116]. In this situation, a promising agent is sulodexide, a mixture of $80 \%$ fast-moving heparin and $20 \%$ of dermatan sulfate. Sulodexide has antithrombotic, profibrinolytic, anti-inflammatory, antioxidant, and anti-ischemic properties. In addition, its proposed mode of action is the inhibition of heparanase and also the modulation of MMP-9 production [127]. Animal models revealed multifaceted effects of sulodexide on endothelial functions $[127,129]$, and, in clinical evaluation, sulodexide was able to partially restore endothelial glycocalyx and vascular permeability in patients with type 2 diabetes $[130,131]$.

- Another element that could help to maintain glycocalyx integrity in diabetes is atrasentan and metformin. Atrasentan, antagonizing endothelin-1, reduces the glomerular expression of heparanase and its activator cathepsin-L [73]. The mechanism of action of metformin has not yet been clarified, but two weeks of metformin in drinking water is associated with an improvement in glycocalyx barrier properties in $\mathrm{db} / \mathrm{db}$ mice [132].

- Since MMPs are central elements in glycocalyx degradation, some attempts at inhibition have been made, but more cell and animal experiments are necessary for a clinical translation. In vitro, sphingosine-1-phosphate (S1P) inhibits MMP-9 and -13 activity by activating the S1P1 receptor, which restores the endothelial glycocalyx through the activation of the PI3K pathway. S1P by inhibiting MMPs prevents the shedding of CS, HS, and the syndecan-1 ectodomain [133,134]. The use of pan-MMPs inhibitors, however, is not viable [135]. Some studies have shown that specific MMP-2 and -9 inhibition prevent the shedding of SDC- 4 and HS in response to TNF- $\alpha$ preserving glycocalyx integrity [63,136].

- Another strategy to protect and reconstitute damaged glycocalyx is to supply endothelial cells with glycocalyx components. It has been proved, in an in vivo model, that glycocalyx damaged by hyaluronidase treatment can be partially recovered by acute infusion of hyaluronan and chondroitin sulfate [137]. It has also been proposed that the use of glycocalyx-mimetic biomaterials such as corline heparin conjugate, a structure resembling a proteoglycan, is able to protect the vasculature in thrombotic disorders and organ transplantation [138]. Additionally, elements designed to improve the compatibility between blood and polymeric biomaterials, such as the glycocalyx-mimetic dextran-modified poly(vinyl amine) surfactant, could represent useful tools to ameliorate glycocalyx structure [139].

- Possible strategies in future could implement NO production through the use of small molecules such as the protein kinase $\mathrm{C}$ inhibitor midostaurin, the pentacyclic triterpenoids ursolic acid and betulinic acid, the eNOS-enhancing compounds AVE9488 and AVE3085, and the polyphenolic phytoalexin transresveratrol [140].

- Giving the central role of SIRT-1 on endothelial glycocalyx preservation strategies aimed at restoration of its expression and activity are currently being tested [141]. The first generation of SIRT1 activators were plant polyphenols, such as butein, piceatannol, isoliquiritigenin, and mostly resveratrol $[142,143]$. Advances in sirtuin biochemistry, 
assays, and crystal structures allowed the development of more specific SIRT-1 modulators. Three small-molecule SIRT1 activators (SRT2104, SRT2379, and SRT3025) have been tested in clinical trials. All the compounds were well tolerated. In three studies, in elderly volunteers, healthy cigarette smokers, and type 2 diabetics, the compound SRT2104 had a beneficial effect on lipids, decreasing serum cholesterol, LDL levels, and triglycerides [139]. SRT2104 also reduced the LPS-induced release of inflammatory mediators and activation of coagulation [144]. Other studies have been carried out to test the anti-inflammatory effects of SRT2104 [141]. Starting from this evidence, the evaluation of these compounds' effects on glycocalyx preservation and the regulation of fibrosis would be desirable to be made.

- It has been described that the patchy degradation of ESG is a result of the exocytosis of lysosome-related organelles. The control of excessive exocytosis could be achieved by sustaining NO production such as with NG-hydroxy-l-arginine, a nitric oxide intermediate [145].

- A new and promising strategy to obtain the restoration of glycocalyx is the recently described nanoliposomal carriers of preassembled glycocalyx [146]. These structures are able to bind to cells with degraded glycocalyx and restore NO production in endothelial cells, and they are able to induce a flow-induced vasodilatory response in perfused mesenteric arteries with a degraded glycocalyx [146].

\section{Conclusions}

In conclusion, since the endothelial glycocalyx has a crucial role in the development of organ fibrosis further research is needed to translate to the clinic new strategies to maintain and reconstitute glycocalyx integrity.

Author Contributions: Conceptualization, V.M., M.O., and G.G.; Writing, V.M., G.Z., and A.A.; Supervision, A.A., M.O., and G.G. All authors have read and agreed to the published version of the manuscript.

Funding: This work was supported by a grant provided by the University of Padova (BIRD192859/19)

Conflicts of Interest: The authors declare no conflict of interest.

\section{References}

1. Augustin, H.G.; Koh, G.Y. Organotypic vasculature: From descriptive heterogeneity to functional pathophysiology. Science 2017, 357, eaal2379. [CrossRef] [PubMed]

2. Jourde-Chiche, N.; Fakhouri, F.; Dou, L.; Bellien, J.; Burtey, S.; Frimat, M.; Jarrot, P.A.; Kaplanski, G.; Le Quintrec, M.; Pernin, V.; et al. Endothelium structure and function in kidney health and disease. Nat. Rev. Nephrol. 2019, 15, 87-108. [CrossRef] [PubMed]

3. Vink, H.; Duling, B.R. Capillary endothelial surface layer selectively reduces plasma solute distribution volume. Am. J. Physiol. Heart Circ. Physiol. 2000, 278, H285-H289. [CrossRef]

4. Uchimido, R.; Schmidt, E.P.; Shapiro, N.I. The glycocalyx: A novel diagnostic and therapeutic target in sepsis. Crit. Care 2019, 23, 16. [CrossRef]

5. Cai, H.; Harrison, D.G. Endothelial dysfunction in cardiovascular diseases: The role of oxidant stress. Circ. Res. 2000, 87, 840-844. [CrossRef] [PubMed]

6. Verma, S.K.; Molitoris, B.A. Renal endothelial injury and microvascular dysfunction in acute kidney injury. Semin. Nephrol. 2015, 35, 96-107. [CrossRef]

7. Jia, G.; Aroor, A.R.; Jia, C.; Sowers, J.R. Endothelial cell senescence in aging-related vascular dysfunction. Biochim. Biophys. Acta Mol. Basis Dis. 2019, 1865, 1802-1809. [CrossRef] [PubMed]

8. Reitsma, S.; Slaaf, D.W.; Vink, H.; van Zandvoort, M.A.; oude Egbrink, M.G. The endothelial glycocalyx: Composition, functions, and visualization. Pflugers Arch. 2007, 454, 345-359. [CrossRef]

9. Van Teeffelen, J.W.; Brands, J.; Stroes, E.S.; Vink, H. Endothelial glycocalyx: Sweet shield of blood vessels. Trends Cardiovasc. Med. 2007, 17, 101-105. [CrossRef] [PubMed]

10. Prydz, K. Determinants of Glycosaminoglycan (GAG) Structure. Biomolecules 2015, 5, 2003. [CrossRef] [PubMed]

11. Esko, J.D.; Kimata, K.; Lindahl, U. Proteoglycans and Sulfated Glycosaminoglycans. Essentials of Glycobiology, 2nd ed.; Varki, A., Cummings, R.D., Esko, J.D., Freeze, H.H., Stanley, P., Bertozzi, C.R., Hart, G.W., Etzler, M.E., Eds.; Cold Spring Harbor Laboratory Press: Cold Spring Harbor, NY, USA, 2009.

12. Curry, F.R. Microvascular solute and water transport. Microcirculation 2005, 12, 17-31. [CrossRef] 
13. Rabelink, T.J.; van den Berg, B.M.; Garsen, M.; Wang, G.; Elkin, M.; van der Vlag, J. Heparanase: Roles in cell survival, extracellular matrix remodelling and the development of kidney disease. Nat. Rev. Nephrol. 2017, 13, 201-212. [CrossRef] [PubMed]

14. Lennon, F.E.; Singleton, P.A. Hyaluronan regulation of vascular integrity. Am. J. Cardiovasc. Dis. 2011, 1, 200-213. [PubMed]

15. Tkachenko, E.; Rhodes, J.M.; Simons, M. Syndecans: New kids on the signaling block. Circ. Res. 2005, 96, 488-500. [CrossRef] [PubMed]

16. Aikawa, T.; Whipple, C.A.; Lopez, M.E.; Gunn, J.; Young, A.; Lander, A.D.; Korc, M. Glypican-1 modulates the angiogenic and metastatic potential of human and mouse cancer cells. J. Clin. Investig. 2008, 118, 89-99. [CrossRef] [PubMed]

17. Bar-Shavit, R.; Maoz, M.; Ginzburg, Y.; Vlodavsky, I. Specific involvement of glypican in thrombin adhesive properties. J. Cell Biochem. 1996, 61, 278-291. [CrossRef]

18. Koedam, J.A.; Cramer, E.M.; Briend, E.; Furie, B.; Furie, B.C.; Wagner, D.D. P-selectin, a granule membrane protein of platelets and endothelial cells, follows the regulated secretory pathway in AtT-20 cells. J. Cell Biol. 1992, 116, 617-625. [CrossRef]

19. Jung, U.; Ley, K. Regulation of E-selectin, P-selectin, and intercellular adhesion molecule 1 expression in mouse cremaster muscle vasculature. Microcirculation 1997, 4, 311-319. [CrossRef] [PubMed]

20. Sperandio, M. Selectins and glycosyltransferases in leukocyte rolling in vivo. FEBS J. 2006, 273, 4377-4389. [CrossRef] [PubMed]

21. De Franceschi, N.; Hamidi, H.; Alanko, J.; Sahgal, P.; Ivaska, J. Integrin traffic-The update. J. Cell Sci. 2015, 128, 839-852. [CrossRef] [PubMed]

22. Bombeli, T.; Schwartz, B.R.; Harlan, J.M. Adhesion of activated platelets to endothelial cells: Evidence for a GPIIbIIIa-dependent bridging mechanism and novel roles for endothelial intercellular adhesion molecule 1 (ICAM-1), alphavbeta3 integrin, and GPIbalpha. J. Exp. Med. 1998, 187, 329-339. [CrossRef]

23. Rüegg, C.; Mariotti, A. Vascular integrins: Pleiotropic adhesion and signaling molecules in vascular homeostasis and angiogenesis. Cell Mol. Life Sci. 2003, 60, 1135-1157. [CrossRef]

24. Müller, A.M.; Hermanns, M.I.; Cronen, C.; Kirkpatrick, C.J. Comparative study of adhesion molecule expression in cultured human macro- and microvascular endothelial cells. Exp. Mol. Pathol. 2002, 73, 171-180. [CrossRef]

25. Yang, X.; Meegan, J.E.; Jannaway, M.; Coleman, D.C.; Yuan, S.Y. A disintegrin and metalloproteinase 15-mediated glycocalyx shedding contributes to vascular leakage during inflammation. Cardiovasc. Res. 2018, 114, 1752-1763. [CrossRef]

26. Lipowsky, H.H. Microvascular rheology and hemodynamics. Microcirculation 2005, 12, 5-15. [CrossRef]

27. Curry, F.E. Layer upon layer: The functional consequences of disrupting the glycocalyx-endothelial barrier in vivo and in vitro. Cardiovasc. Res. 2017, 113, 559-561. [CrossRef] [PubMed]

28. Pries, A.R.; Secomb, T.W.; Gaehtgens, P. The endothelial surface layer. Pflugers Arch. 2000, 440, 653-666. [CrossRef] [PubMed]

29. Yoon, J.H.; Lee, E.S.; Jeong, Y. In vivo Imaging of the Cerebral Endothelial Glycocalyx in Mice. J. Vasc. Res. 2017, 54, 59-67. [CrossRef] [PubMed]

30. Liu, H.B.; Zhang, J.; Xin, S.Y.; Liu, C.; Wang, C.Y.; Zhao, D.; Zhang, Z.R. Mechanosensitive properties in the endothelium and their roles in the regulation of endothelial function. J. Cardiovasc. Pharmacol. 2013, 61, 461-470. [CrossRef]

31. Tarbell, J.M.; Simon, S.I.; Curry, F.R. Mechanosensing at the vascular interface. Annu. Rev. Biomed. Eng. 2014, 16, 505-532. [CrossRef]

32. Rubanyi, G.M.; Romero, J.C.; Vanhoutte, P.M. Flow-induced release of endothelium-derived relaxing factor. Am. J. Physiol. 1986, 250 Pt 2, H1145-H1149. [CrossRef]

33. Chappell, D.; Westphal, M.; Jacob, M. The impact of the glycocalyx on microcirculatory oxygen distribution in critical illness. Curr. Opin. Anaesthesiol. 2009, 22, 155-162. [CrossRef] [PubMed]

34. Oberleithner, H. Vascular endothelium: A vulnerable transit zone for merciless sodium. Nephrol. Dial. Transplant. 2014, 29, 240-246. [CrossRef]

35. Dull, R.O.; Mecham, I.; McJames, S. Heparan sulfates mediate pressure-induced increase in lung endothelial hydraulic conductivity via nitric oxide/reactive oxygen species. Am. J. Physiol. Lung Cell Mol. Physiol. 2007, 292, L1452-L1458. [CrossRef]

36. Dull, R.O.; Cluff, M.; Kingston, J.; Hill, D.; Chen, H.; Hoehne, S.; Malleske, D.T.; Kaur, R. Lung heparan sulfates modulate K(fc) during increased vascular pressure: Evidence for glycocalyx-mediated mechanotransduction. Am. J. Physiol. Lung Cell. Mol. Physiol. 2012, 302, L816-L828. [CrossRef] [PubMed]

37. Betteridge, K.B.; Arkill, K.P.; Neal, C.R.; Harper, S.J.; Foster, R.R.; Satchell, S.C.; Bates, D.O.; Salmon, A.H.J. Sialic acids regulate microvessel permeability, revealed by novel in vivo studies of endothelial glycocalyx structure and function. Atherosclerosis 2017, $595,5015-5035$.

38. Iba, T.; Levy, J.H. Derangement of the endothelial glycocalyx in sepsis. J. Thromb. Haemost. 2019, 17, 283-294. [CrossRef]

39. Dreyfuss, J.L.; Regatieri, C.V.; Jarrouge, T.R.; Cavalheiro, R.P.; Sampaio, L.O.; Nader, H.B. Heparan sulfate proteoglycans: Structure, protein interactions and cell signaling. An. Acad. Bras. Cienc. 2009, 81, 409-429. [CrossRef]

40. Prior, S.M.; Cohen, M.J.; Conroy, A.S.; Nelson, M.F.; Kornblith, L.Z.; Howard, B.M.; Butenas, S. Correlation between factor (F)XIa, FIXa and tissue factor and trauma severity. J. Trauma Acute Care Surg. 2017, 82, 1073-1079. [CrossRef] [PubMed]

41. Malik, A.B.; Lo, S.K.; Bizios, R. Thrombin-induced alterations in endothelial permeability. Ann. N. Y. Acad. Sci. 1986, 485, 293-309. [CrossRef] [PubMed]

42. Klarenbach, S.W.; Chipiuk, A.; Nelson, R.C.; Hollenberg, M.D.; Murray, A.G. Differential actions of PAR2 and PAR1 in stimulating human endothelial cell exocytosis and permeability: The role of Rho-GTPases. Circ. Res. 2003, 92, 272-278. [CrossRef] [PubMed] 
43. Van Golen, R.F.; Reiniers, M.J.; Vrisekoop, N.; Zuurbier, C.J.; Olthof, P.B.; van Rheenen, J.; van Gulik, T.M.; Parsons, B.J.; Heger, M. The mechanisms and physiological relevance of glycocalyx degradation in hepatic ischemia/reperfusion injury. Antioxid. Redox Signal. 2014, 21, 1098-1118. [CrossRef]

44. Moseley, R.; Waddington, R.J.; Embery, G. Degradation of glycosaminoglycans by reactive oxygen species derived from stimulated polymorphonuclear leukocytes. Biochim. Biophys. Acta 1997, 1362, 221-231. [CrossRef]

45. Soltés, L.; Mendichi, R.; Kogan, G.; Schiller, J.; Stankovska, M.; Arnhold, J. Degradative action of reactive oxygen species on hyaluronan. Biomacromolecules 2006, 7, 659-668. [CrossRef]

46. Safrankova, B.; Gajdova, S.; Kubala, L. The potency of hyaluronan of different molecular weights in the stimulation of blood phagocytes. Mediat. Inflamm. 2010, 2010, 380948. [CrossRef]

47. Castro, M.M.; Rizzi, E.; Figueiredo-Lopes, L.; Fernandes, K.; Bendhack, L.M.; Pitol, D.L.; Gerlach, R.F.; Tanus-Santos, J.E. Metalloproteinase inhibition ameliorates hypertension and prevents vascular dysfunction and remodeling in renovascular hypertensive rats. Atherosclerosis 2008, 198, 320-331. [CrossRef]

48. Hobeika, M.J.; Thompson, R.W.; Muhs, B.E.; Brooks, P.C.; Gagne, P.J. Matrix metalloproteinases in peripheral vascular disease. J. Vasc. Surg. 2007, 45, 849-857. [CrossRef] [PubMed]

49. Sieve, I.; Münster-Kühnel, A.K.; Hilfiker-Kleiner, D. Regulation and function of endothelial glycocalyx layer in vascular diseases. Vasc. Pharmacol. 2018, 100, 26-33. [CrossRef] [PubMed]

50. Bogner-Flatz, V.; Braunstein, M.; Ocker, L.E.; Kusmenkov, T.; Tschoep, J.; Ney, L.; Böcker, W.; Annecke, T. On-the-Scene Hyaluronan and Syndecan-1 Serum Concentrations and Outcome after Cardiac Arrest and Resuscitation. Mediat. Inflamm. 2019, 2019, 8071619. [CrossRef] [PubMed]

51. Masola, V.; Zaza, G.; Gambaro, G.; Franchi, M.; Onisto, M. Role of heparanase in tumor progression: Molecular aspects and therapeutic options. Semin. Cancer Biol. 2020, 62, 86-98. [CrossRef]

52. Masola, V.; Bellin, G.; Gambaro, G.; Onisto, M. Heparanase: A Multitasking Protein Involved in Extracellular Matrix (ECM) Remodeling and Intracellular Events. Cells 2018, 7, 236. [CrossRef] [PubMed]

53. Kramer, A.; van den Hoven, M.; Rops, A.; Wijnhoven, T.; van den Heuvel, L.; Lensen, J.; van Kuppevelt, T.; van Goor, H.; van der Vlag, J.; Navis, G.; et al. Induction of glomerular heparanase expression in rats with adriamycin nephropathy is regulated by reactive oxygen species and the renin-angiotensin system. J. Am. Soc. Nephrol. 2006, 17, 2513-2520. [CrossRef]

54. Chen, G.; Wang, D.; Vikramadithyan, R.; Yagyu, H.; Saxena, U.; Pillarisetti, S.; Goldberg, I.J. Inflammatory cytokines and fatty acids regulate endothelial cell heparanase expression. Biochemistry 2004, 43, 4971-4977. [CrossRef] [PubMed]

55. Han, J.; Mandal, A.K.; Hiebert, L.M. Endothelial cell injury by high glucose and heparanase is prevented by insulin, heparin and basic fibroblast growth factor. Cardiovasc. Diabetol. 2005, 4, 12. [CrossRef]

56. An, X.F.; Zhou, L.; Jiang, P.J.; Yan, M.; Huang, Y.J.; Zhang, S.N.; Niu, Y.F.; Ten, S.C.; Yu, J.Y. Advanced glycation end-products induce heparanase expression in endothelial cells by the receptor for advanced glycation end products and through activation of the FOXO4 transcription factor. Mol. Cell Biochem. 2011, 354, 47-55. [CrossRef] [PubMed]

57. Ishai-Michaeli, R.; Eldor, A.; Vlodavsky, I. Heparanase activity expressed by platelets, neutrophils, and lymphoma cells releases active fibroblast growth factor from extracellular matrix. Cell Regul. 1990, 1, 833-842. [CrossRef] [PubMed]

58. Pomin, V.H. Sulfated glycans in inflammation. Eur. J. Med. Chem. 2015, 92, 353-369. [CrossRef]

59. Garsen, M.; Rops, A.L.; Rabelink, T.J.; Berden, J.H.; van der Vlag, J. The role of heparanase and the endothelial glycocalyx in the development of proteinuria. Nephrol. Dial. Transplant. 2014, 29, 49-55. [CrossRef]

60. Lever, R.; Rose, M.J.; McKenzie, E.A.; Page, C.P. Heparanase induces inflammatory cell recruitment in vivo by promoting adhesion to vascular endothelium. Am. J. Physiol. Cell. Physiol. 2014, 306, C1184-C1190. [CrossRef]

61. Ilan, N.; Elkin, M.; Vlodavsky, I. Regulation, function and clinical significance of heparanase in cancer metastasis and angiogenesis. Int. J. Biochem. Cell Biol. 2006, 38, 2018-2039. [CrossRef] [PubMed]

62. Blich, M.; Golan, A.; Arvatz, G.; Sebbag, A.; Shafat, I.; Sabo, E.; Cohen-Kaplan, V.; Petcherski, S.; Avniel-Polak, S.; Eitan, A.; et al. Macrophage activation by heparanase is mediated by TLR-2 and TLR-4 and associates with plaque progression. Arterioscler Thromb. Vasc. Biol. 2013, 33, e56-e65. [CrossRef] [PubMed]

63. Ramnath, R.; Foster, R.R.; Qiu, Y.; Cope, G.; Butler, M.J.; Salmon, A.H.; Mathieson, P.W.; Coward, R.J.; Welsh, G.I.; Satchell, S.C. Matrix metalloproteinase 9-mediated shedding of syndecan 4 in response to tumor necrosis factor $\alpha$ : A contributor to endothelial cell glycocalyx dysfunction. FASEB J. 2014, 28, 4686-4699. [CrossRef]

64. Nadir, Y.; Brenner, B. Heparanase procoagulant activity in cancer progression. Thromb. Res. 2016, 140 (Suppl. 1), S44-S48. [CrossRef]

65. Traister, A.; Shi, W.; Filmus, J. Mammalian Notum induces the release of glypicans and other GPI-anchored proteins from the cell surface. Biochem. J. 2008, 410, 503-511. [CrossRef] [PubMed]

66. Yamaoka-Tojo, M. Vascular Endothelial Glycocalyx Damage in COVID-19. Int. J. Mol. Sci. 2020, 21, 9712. [CrossRef] [PubMed]

67. Solbu, M.D.; Kolset, S.O.; Jenssen, T.G.; Wilsgaard, T.; Løchen, M.L.; Mathiesen, E.B.; Melsom, T.; Eriksen, B.O.; Reine, T.M. Gender differences in the association of syndecan- 4 with myocardial infarction: The population-based Tromsø Study. Atherosclerosis 2018, 278, 166-173. [CrossRef]

68. Kataoka, H.; Ushiyama, A.; Akimoto, Y.; Matsubara, S.; Kawakami, H.; Iijima, T. Structural behavior of the endothelial glycocalyx is associated with pathophysiologic status in septic mice: An integrated approach to analyzing the behavior and function of the glycocalyx using both electron and fluorescence intravital microscopy. Anesth. Analg. 2017, 125, 874-883. [CrossRef] 
69. Schmidt, E.P.; Yang, Y.; Janssen, W.J.; Gandjeva, A.; Perez, M.J.; Barthel, L.; Zemans, R.L.; Bowman, J.C.; Koyanagi, D.E.; Yunt, Z.X.; et al. The pulmonary endothelial glycocalyx regulates neutrophil adhesion and lung injury during experimental sepsis. Nat. Med. 2012, 18, 1217-1223. [CrossRef] [PubMed]

70. Xu, C.; Chang, A.; Hack, B.K.; Eadon, M.T.; Alper, S.L. Cunningham PN. TNF-mediated damage to glomerular endothelium is an important determinant of acute kidney injury in sepsis. Kidney Int. 2014, 85, 72-81. [CrossRef] [PubMed]

71. Yang, Y.; Haeger, S.M.; Suflita, M.A.; Zhang, F.; Dailey, K.L.; Colbert, J.F.; Ford, J.A.; Picon, M.A.; Stearman, R.S.; Lin, L.; et al. Fibroblast Growth Factor Signaling Mediates Pulmonary Endothelial Glycocalyx Reconstitution. Am. J. Respir. Cell Mol. Biol. 2017, 56, 727-737. [CrossRef] [PubMed]

72. Nagy, N.; Freudenberger, T.; Melchior-Becker, A.; Röck, K.; Ter Braak, M.; Jastrow, H.; Kinzig, M.; Lucke, S.; Suvorava, T.; Kojda G.; et al. Inhibition of hyaluronan synthesis accelerates murine atherosclerosis: Novel insights into the role of hyaluronan synthesis. Circulation 2010, 122, 2313-2322. [CrossRef] [PubMed]

73. Boels, M.G.; Avramut, M.C.; Koudijs, A.; Dane, M.J.; Lee, D.H.; van der Vlag, J.; Koster, A.J.; van Zonneveld, A.J.; van Faassen, E.; Gröne, H.J.; et al. Atrasentan Reduces Albuminuria by Restoring the Glomerular Endothelial Glycocalyx Barrier in Diabetic Nephropathy. Diabetes 2016, 65, 2429-2439. [CrossRef]

74. Mc Donald, K.K.; Cooper, S.; Danielzak, L.; Leask, R.L. Glycocalyx degradation induces a proinflammatory phenotype and increased leukocyte adhesion in cultured endothelial cells under flow. PLoS ONE 2016, 11, e0167576.

75. Torres Filho, I.P.; Torres, L.N.; Salgado, C.; Dubick, M.A. Plasma syndecan-1 and heparan sulfate correlate with icrovascular glycocalyx degradation in hemorrhaged rats after different resuscitation fluids. Am. J. Physiol. Heart Circ. Physiol. 2016, 310, H1468-H1478. [CrossRef] [PubMed]

76. Yini, S.; Heng, Z.; Xin, A.; Xiaochun, M. Effect of unfractionated heparin on endothelial glycocalyx in a septic shock model. Acta Anaesthesiol. Scand. 2015, 59, 160-169. [CrossRef]

77. Abassi, Z.; Hamoud, S.; Hassan, A.; Khamaysi, I.; Nativ, O.; Heyman, S.N.; Muhammad, R.S.; Ilan, N.; Singh, P.; Hammond, E.; et al. Involvement of heparanase in the pathogenesis of acute kidney injury: Nephroprotective effect of PG545. Oncotarget 2017, 8, 34191-34204. [CrossRef]

78. Annecke, T.; Chappell, D.; Chen, C.; Jacob, M.; Welsch, U.; Sommerhoff, C.P.; Rehm, M.; Conzen, P.F.; Becker, B.F. Sevoflurane preserves the endothelial glycocalyx against ischaemia-reperfusion injury. Br. J. Anaesth. 2010, 104, 414-421. [CrossRef] [PubMed]

79. Rehm, M.; Bruegger, D.; Christ, F.; Conzen, P.; Thiel, M.; Jacob, M.; Chappell, D.; Stoeckelhuber, M.; Welsch, U.; Reichart, B.; et al. Shedding of the endothelial glycocalyx in patients undergoing major vascular surgery with global and regional ischemia. Circulation 2007, 116, 1896-1906. [CrossRef]

80. King, M.L.R.; Salmon, A.E.; Saleem, M.A.; Welsh, G.I.; Michel, C.C.; Satchell, S.C.; Salmon, A.H.J.; Foster, R.R. A novel assay provides sensitive measurement of physiologically relevant changes in albumin permeability in isolated human and rodent glomeruli. Kidney Int. 2018, 93, e1086-e1097.

81. Diebel, L.N.; Liberati, D.M.; Martin, J.V. Acute hyperglycemia increases sepsis related glycocalyx degradation and endothelial cellular injury: A microfluidic study. Am. J. Surg. 2019, 217, 1076-1082. [CrossRef] [PubMed]

82. Schenning, K.J.; Anderson, S.; Alkayed, N.J.; Hutchens, M.P. Hyperglycemia abolishes the protective effect of ischemic preconditioning in glomerular endothelial cells in vitro. Physiol. Rep. 2015, 3, e12346. [CrossRef]

83. Gupta, A.; Madhavan, M.V.; Sehgal, K.; Nair, N.; Mahajan, S.; Sehrawat, T.S.; Bikdeli, B.; Ahluwalia, N.; Ausiello, J.C.; Wan, E.Y.; et al. Extrapulmonary manifestations of COVID-19. Nat Med. 2020, 26, 1017-1032. [CrossRef] [PubMed]

84. Suzuki, K.; Okada, H.; Tomita, H.; Sumi, K.; Kakino, Y.; Yasuda, R.; Kitagawa, Y.; Fukuta, T.; Miyake, T.; Yoshida, S.; et al. Possible involvement of Syndecan-1 in the state of COVID-19 related to endothelial injury. Thromb. J. 2021, 19, 5. [CrossRef]

85. Masola, V.; Gambaro, G.; Onisto, M. Impact of Heparanse on Organ Fibrosis. Adv. Exp. Med. Biol. 2020, 1221, 669-684. [PubMed]

86. LeBleu, V.S.; Taduri, G.; O'Connell, J.; Teng, Y.; Cooke, V.G.; Woda, C.; Sugimoto, H.; Kalluri, R. Origin and function of myofibroblasts in kidney fibrosis. Nat. Med. 2013, 19, 1047-1053. [CrossRef] [PubMed]

87. Zaza, G.; Masola, V.; Granata, S.; Pontrelli, P.; Sallustio, F.; Gesualdo, L.; Gambaro, G.; Grandaliano, G.; Lupo, A. Dialysis-related transcriptomic profiling: The pivotal role of heparanase. Exp. Biol. Med. 2014, 239, 52-64. [CrossRef]

88. Masola, V.; Bellin, G.; Vischini, G.; Dall'Olmo, L.; Granata, S.; Gambaro, G.; Lupo, A.; Onisto, M.; Zaza, G. Inhibition of heparanase protects against chronic kidney dysfunction following ischemia/reperfusion injury. Oncotarget 2018, 9, 36185-36201. [CrossRef]

89. Masola, V.; Zaza, G.; Gambaro, G.; Onisto, M.; Bellin, G.; Vischini, G.; Khamaysi, I.; Hassan, A.; Hamoud, S.; Nativ, O.; et al. Heparanase: A Potential New Factor Involved in the Renal Epithelial Mesenchymal Transition (EMT) Induced by Ischemia/Reperfusion (I/R) Injury. PLoS ONE 2016, 11, e0160074. [CrossRef] [PubMed]

90. Masola, V.; Gambaro, G.; Tibaldi, E.; Onisto, M.; Abaterusso, C.; Lupo, A. Regulation of heparanase by albumin and advanced glycation end products in proximal tubular cells. Biochim. Biophys. Acta 2011, 1813, 1475-1482. [CrossRef]

91. Gil, N.; Goldberg, R.; Neuman, T.; Garsen, M.; Zcharia, E.; Rubinstein, A.M.; van Kuppevelt, T.; Meirovitz, A.; Pisano, C.; Li, J.P.; et al. Heparanase is essential for the development of diabetic nephropathy in mice. Diabetes 2012, 61, 208-216. [CrossRef]

92. Masola, V.; Zaza, G.; Secchi, M.F.; Gambaro, G.; Lupo, A.; Onisto, M. Heparanase is a key player in renal fibrosis by regulating TGF- $\beta$ expression and activity. Biochim. Biophys. Acta 2014, 1843, 2122-2128. [CrossRef]

93. Masola, V.; Onisto, M.; Zaza, G.; Lupo, A.; Gambaro, G. A new mechanism of action of sulodexide in diabetic nephropathy: Inhibits heparanase-1 and prevents FGF-2-induced renal epithelial-mesenchymal transition. J. Transl. Med. 2012, 10, 213. [CrossRef] [PubMed] 
94. Masola, V.; Zaza, G.; Bellin, G.; Dall'Olmo, L.; Granata, S.; Vischini, G.; Secchi, M.F.; Lupo, A.; Gambaro, G.; Onisto, M. Heparanase regulates the M1 polarization of renal macrophages and their crosstalk with renal epithelial tubular cells after ischemia/reperfusion injury. FASEB J. 2018, 32, 742-756. [CrossRef] [PubMed]

95. Rossi, G.P.; Seccia, T.M.; Barton, M.; Danser, A.H.J.; de Leeuw, P.W.; Dhaun, N.; Rizzoni, D.; Rossignol, P.; Ruilope, L.M.; van den Meiracker, A.H.; et al. Endothelial factors in the pathogenesis and treatment of chronic kidney disease Part I: General mechanisms: A joint consensus statement from the European Society of Hypertension Working Group on Endothelin and Endothelial Factors and The Japanese Society of Hypertension. J. Hypertens. 2018, 36, 451-461. [PubMed]

96. Rossi, G.P.; Sacchetto, A.; Cesari, M.; Pessina, A.C. Interactions between endothelin-1 and the renin-angiotensin-aldosterone system. Cardiovasc. Res. 1999, 43, 300-307. [CrossRef]

97. Clozel, M.; Salloukh, H. Role of endothelin in fibrosis and anti-fibrotic potential of bosentan. Ann. Med. 2005, 37, 2-12. [CrossRef] [PubMed]

98. Neuhofer, W.; Pittrow, D. Role of endothelin and endothelin receptor antagonists in renal disease. Eur. J. Clin. Investig. 2006, 36 (Suppl. 3), 78-88. [CrossRef] [PubMed]

99. Garsen, M.; Lenoir, O.; Rops, A.L.; Dijkman, H.B.; Willemsen, B.; van Kuppevelt, T.H.; Rabelink, T.J.; Berden, J.H.; Tharaux, P.L.; van der Vlag, J. Endothelin-1 Induces Proteinuria by Heparanase-Mediated Disruption of the Glomerular Glycocalyx. J. Am. Soc. Nephrol. 2016, 27, 3545-3551. [CrossRef]

100. Van den Hoven, M.J.; Waanders, F.; Rops, A.L.; Kramer, A.B.; van Goor, H.; Berden, J.H.; Navis, G.; van der Vlag, J. Regulation of glomerular heparanase expression by aldosterone, angiotensin II and reactive oxygen species. Nephrol. Dial. Transplant. 2009, 24, 2637-2645. [CrossRef]

101. Shafat, I.; Ilan, N.; Zoabi, S.; Vlodavsky, I.; Nakhoul, F. Heparanase levels are elevated in the urine and plasma of type 2 diabetes patients and associate with blood glucose levels. PLoS ONE 2011, 6, e17312. [CrossRef] [PubMed]

102. Wang, F.; Kim, M.S.; Puthanveetil, P.; Kewalramani, G.; Deppe, S.; Ghosh, S.; Abrahani, A.; Rodrigues, B. Endothelial heparanase secretion after acute hypoinsulinemia is regulated by glucose and fatty acid. Am. J. Physiol. Heart Circ. Physiol. 2009, 296, H1108-H1116. [CrossRef]

103. Han, J.; Hiebert, L.M. Alteration of endothelial proteoglycan and heparanase gene expression by high glucose, insulin and heparin. Vasc. Pharmacol. 2013, 59, 112-118. [CrossRef]

104. Goldberg, R.; Sonnenblick, A.; Hermano, E.; Hamburger, T.; Meirovitz, A.; Peretz, T.; Elkin, M. Heparanase augments insulin receptor signaling in breast carcinoma. Oncotarget 2017, 8, 19403-19412. [CrossRef] [PubMed]

105. Purushothaman, A.; Babitz, S.K.; Sanderson, R.D. Heparanase enhances the insulin receptor signaling pathway to activate extracellular signal-regulated kinase in multiple myeloma. J. Biol. Chem. 2012, 287, 41288-41296. [CrossRef]

106. King, G.L.; Park, K.; Li, Q. Selective Insulin Resistance and the Development of Cardiovascular Diseases in Diabetes: The 2015 Edwin Bierman Award Lecture. Diabetes 2016, 65, 1462-1471. [CrossRef] [PubMed]

107. Bazyluk, A.; Malyszko, J.; Hryszko, T.; Zbroch, E. State of the art—sirtuin 1 in kidney pathology-clinical relevance. Adv. Med. Sci. 2019, 64, 356-364. [CrossRef]

108. Lipphardt, M.; Dihazi, H.; Müller, G.A.; Goligorsky, M.S. Fibrogenic Secretome of Sirtuin 1-Deficient Endothelial Cells: Wnt, Notch and Glycocalyx Rheostat. Front. Physiol. 2018, 9, 1325. [CrossRef] [PubMed]

109. Vasko, R.; Xavier, S.; Chen, J.; Lin, C.H.; Ratliff, B.; Rabadi, M.; Maizel, J.; Tanokuchi, R.; Zhang, F.; Cao, J.; et al. Endothelial sirtuin 1 deficiency perpetrates nephrosclerosis through downregulation of matrix metalloproteinase-14: Relevance to fibrosis of vascular senescence. J. Am. Soc. Nephrol. 2014, 25, 276-291. [CrossRef]

110. Kim, H.; Baek, C.H.; Lee, R.B.; Chang, J.W.; Yang, W.S.; Lee, S.K. Anti-Fibrotic Effect of Losartan, an Angiotensin II Receptor Blocker, Is Mediated through Inhibition of ER Stress via Up-Regulation of SIRT1, Followed by Induction of HO-1 and Thioredoxin. Int. J. Mol. Sci. 2017, 18, 305. [CrossRef] [PubMed]

111. Xing, Z.; Pan, W.; Zhang, J.; Xu, X.; Zhang, X.; He, X.; Fan, M. Hydrogen Rich Water Attenuates Renal Injury and Fibrosis by Regulation Transforming Growth Factor- $\beta$ Induced Sirt1. Biol. Pharm. Bull. 2017, 40, 610-615. [CrossRef] [PubMed]

112. Huang, X.Z.; Wen, D.; Zhang, M.; Xie, Q.; Ma, L.; Guan, Y.; Ren, Y.; Chen, J.; Hao, C.M. Sirt1 activation ameliorates renal fibrosis by inhibiting the TGF- $\beta$ /Smad3 pathway. J. Cell Biochem. 2014, 115, 996-1005. [CrossRef] [PubMed]

113. Xavier, S.; Vasko, R.; Matsumoto, K.; Zullo, J.A.; Chen, R.; Maizel, J.; Chander, P.N.; Goligorsky, M.S. Curtailing endothelial TGF- $\beta$ signaling is sufficient to reduce endothelial-mesenchymal transition and fibrosis in CKD. J. Am. Soc. Nephrol. 2015, 26, 817-829. [CrossRef] [PubMed]

114. Edeling, M.; Ragi, G.; Huang, S.; Pavenstädt, H.; Susztak, K. Developmental signalling pathways in renal fibrosis: The roles of Notch, Wnt and Hedgehog. Nat. Rev. Nephrol. 2016, 12, 426-439. [CrossRef]

115. Yeung, F.; Hoberg, J.E.; Ramsey, C.S.; Keller, M.D.; Jones, D.R.; Frye, R.A.; Mayo, M.W. Modulation of NF-kappaB-dependent transcription and cell survival by the SIRT1 deacetylase. EMBO J. 2004, 23, 2369-2380. [CrossRef] [PubMed]

116. Strand, M.E.; Herum, K.M.; Rana, Z.A.; Skrbic, B.; Askevold, E.T.; Dahl, C.P.; Vistnes, M.; Hasic, A.; Kvaløy, H.; Sjaastad, I.; et al. Innate immune signaling induces expression and shedding of the heparan sulfate proteoglycan syndecan-4 in cardiac fibroblasts and myocytes, affecting inflammation in the pressure-overloaded heart. FEBS J. 2013, 280, 2228-2247. [CrossRef] [PubMed]

117. Lipphardt, M.; Song, J.W.; Ratliff, B.B.; Dihazi, H.; Müller, G.A.; Goligorsky, M.S. Endothelial dysfunction is a superinducer of syndecan-4: Fibrogenic role of its ectodomain. Am. J. Physiol. Heart Circ. Physiol. 2018, 314, H484-H496. [CrossRef] 
118. Torres, L.N.; Sondeen, J.L.; Ji, L.; Dubick, M.A.; Torres Filho, I. Evaluation of resuscitation fluids on endothelial glycocalyx, venular blood flow, and coagulation function after hemorrhagic shock in rats. J. Trauma Acute Care Surg. 2013, 75, 759-766. [CrossRef]

119. Chappell, D.; Hofmann-Kiefer, K.; Jacob, M.; Rehm, M.; Briegel, J.; Welsch, U.; Conzen, P.; Becker, B.F. TNF-alpha induced shedding of the endothelial glycocalyx is prevented by hydrocortisone and antithrombin. Basic Res. Cardiol. 2009, 104, 78-89. [CrossRef]

120. Cui, N.; Wang, H.; Long, Y.; Su, L.; Liu, D. Dexamethasone Suppressed LPS-Induced Matrix Metalloproteinase and Its Effect on Endothelial Glycocalyx Shedding. Mediat. Inflamm. 2015, 2015, 912726. [CrossRef] [PubMed]

121. Locatelli, F.; Canaud, B.; Eckardt, K.U.; Stenvinkel, P.; Wanner, C.; Zoccali, C. Oxidative stress in end-stage renal disease: An emerging threat to patient outcome. Nephrol. Dial. Transplant. 2003, 18, 1272-1280. [CrossRef]

122. Takahashi, N.; Morimoto, S.; Okigaki, M.; Seo, M.; Someya, K.; Morita, T.; Matsubara, H.; Sugiura, T.; Iwasaka, T. Decreased plasma level of vitamin $\mathrm{C}$ in chronic kidney disease: Comparison between diabetic and non-diabetic patients. Nephrol. Dial. Transplant. 2011, 26, 1252-1257. [CrossRef]

123. Antonello, M.; Montemurro, D.; Bolognesi, M.; Di Pascoli, M.; Piva, A.; Grego, F.; Sticchi, D.; Giuliani, L.; Garbisa, S.; Rossi, G.P. Prevention of hypertension, cardiovascular damage and endothelial dysfunction with green tea extracts. Am. J. Hypertens. 2007, 20, 1321-1328. [CrossRef]

124. Masha, A.; Brocato, L.; Dinatale, S.; Mascia, C.; Biasi, F.; Martina, V. N-acetylcysteine is able to reduce the oxidation status and the endothelial activation after a high-glucose content meal in patients with Type 2 diabetes mellitus. J. Endocrinol. Investig. 2009, 32, 352-356. [CrossRef]

125. Hiebert, L.M.; Jaques, L.B. The observation of heparin on endothelium after injection. Thromb. Res. 1976, 8, 195-204. [CrossRef]

126. Nader, H.B.; Toma, L.; Pinhal, M.A.; Buonassisi, V.; Colburn, P.; Dietrich, C.P. Effect of heparin and dextran sulfate on the synthesis and structure of heparan sulfate from cultured endothelial cells. Semin. Thromb. Hemost. 1991, 17 (Suppl. 1), 47-56. [PubMed]

127. Masola, V.; Zaza, G.; Onisto, M.; Lupo, A.; Gambaro, G. Glycosaminoglycans, proteoglycans and sulodexide and the endothelium: Biological roles and pharmacological effects. Int. Angiol. 2014, 33, 243-254. [PubMed]

128. Young, E. The anti-inflammatory effects of heparin and related compounds. Thromb. Res. 2008, 122, 743-752. [CrossRef] [PubMed]

129. Coccheri, S. Biological and clinical effects of sulodexide in arterial disorders and diseases. Int. Angiol. 2014, 33, $263-274$.

130. Broekhuizen, L.N.; Lemkes, B.A.; Mooij, H.L.; Meuwese, M.C.; Verberne, H.; Holleman, F.; Schlingemann, R.O.; Nieuwdorp, M.; Stroes, E.S.; Vink, H. Effect of sulodexide on endothelial glycocalyx and vascular permeability in patients with type 2 diabetes mellitus. Diabetologia 2010, 53, 2646-2655. [CrossRef]

131. Giantsos-Adams, K.; Lopez-Quintero, V.; Kopeckova, P.; Kopecek, J.; Tarbell, J.M.; Dull, R. Study of the therapeutic benefit of cationic copolymer administration to vascular endothelium under mechanical stress. Biomaterials 2011, 32, 288-294. [CrossRef]

132. Eskens, B.J.; Zuurbier, C.J.; van Haare, J.; Vink, H.; van Teeffelen, J.W. Effects of two weeks of metformin treatment on whole-body glycocalyx barrier properties in db/db mice. Cardiovasc. Diabetol. 2013, 12, 175. [CrossRef] [PubMed]

133. Zeng, Y.; Adamson, R.H.; Curry, F.R.; Tarbell, J.M. Sphingosine-1-phosphate protects endothelial glycocalyx by inhibiting syndecan-1 shedding. Am. J. Physiol. Heart Circ. Physiol. 2014, 306, H363-H372. [CrossRef]

134. Zeng, Y.; Liu, X.H.; Tarbell, J.; Fu, B. Sphingosine 1-phosphate induced synthesis of glycocalyx on endothelial cells. Exp. Cell Res. 2015, 339, 90-95. [CrossRef]

135. Jacob, M.; Saller, T.; Chappell, D.; Rehm, M.; Welsch, U.; Becker, B.F. Physiological levels of A-, B- and C-type natriuretic peptide shed the endothelial glycocalyx and enhance vascular permeability. Basic Res. Cardiol. 2013, 108, 347. [CrossRef] [PubMed]

136. Butler, M.J.; Ramnath, R.; Kadoya, H.; Desposito, D.; Riquier-Brison, A.; Ferguson, J.K.; Onions, K.L.; Ogier, A.S.; ElHegni, H.; Coward, R.J.; et al. Aldosterone induces albuminuria via matrix metalloproteinase-dependent damage of the endothelial glycocalyx. Kidney Int. 2019, 95, 94-107. [CrossRef]

137. Henry, C.B.; Duling, B.R. Permeation of the luminal capillary glycocalyx is determined by hyaluronan. Am. J. Physiol. 1999, 277, H508-H514. [CrossRef]

138. Sedigh, A.; Larsson, R.; Brännström, J.; Magnusson, P.; Larsson, E.; Tufveson, G.; Lorant, T. Modifying the vessel walls in porcine kidneys during machine perfusion. J. Surg. Res. 2014, 191, 455-462. [CrossRef] [PubMed]

139. Gupta, A.S.; Wang, S.; Link, E.; Anderson, E.H.; Hofmann, C.; Lewandowski, J.; Kottke-Marchant, K.; Marchant, R.E. Glycocalyxmimetic dextran-modified poly(vinyl amine) surfactant coating reduces platelet adhesion on medical-grade polycarbonate surface. Biomaterials 2006, 27, 3084-3095. [CrossRef] [PubMed]

140. Förstermann, U.; Li, H. Therapeutic effect of enhancing endothelial nitric oxide synthase (eNOS) expression and preventing eNOS uncoupling. Br. J. Pharmacol. 2011, 164, 213-223. [CrossRef] [PubMed]

141. Dai, H.; Sinclair, D.A.; Ellis, J.L.; Steegborn, C. Sirtuin activators and inhibitors: Promises, achievements, and challenges. Pharmacol. Ther. 2018, 188, 140-154. [CrossRef]

142. Howitz, K.T.; Bitterman, K.J.; Cohen, H.Y.; Lamming, D.W.; Lavu, S.; Wood, J.G.; Zipkin, R.E.; Chung, P.; Kisielewski, A.; Zhang, L.L.; et al. Small molecule activators of sirtuins extend Saccharomyces cerevisiae lifespan. Nature 2003, 425, 191-196. [CrossRef]

143. Gertz, M.; Nguyen, G.T.; Fischer, F.; Suenkel, B.; Schlicker, C.; Fränzel, B.; Tomaschewski, J.; Aladini, F.; Becker, C.; Wolters, D.; et al. A molecular mechanism for direct sirtuin activation by resveratrol. PLoS ONE 2012, 7, e49761. [CrossRef] [PubMed]

144. Van der Meer, A.J.; Scicluna, B.P.; Moerland, P.D.; Lin, J.; Jacobson, E.W.; Vlasuk, G.P.; van der Poll, T. The Selective Sirtuin 1 Activator SRT2104 Reduces Endotoxin-Induced Cytokine Release and Coagulation Activation in Humans. Crit. Care Med. 2015, 43, e199-e202. [CrossRef] 
145. Zullo, J.A.; Fan, J.; Azar, T.T.; Yen, W.; Zeng, M.; Chen, J.; Ratliff, B.B.; Song, J.; Tarbell, J.M.; Goligorsky, M.S.; et al. Exocytosis of Endothelial Lysosome-Related Organelles Hair-Triggers a Patchy Loss of Glycocalyx at the Onset of Sepsis. Am. J. Pathol. 2016, 186, 248-258. [CrossRef] [PubMed]

146. Zhang, X.; Sun, D.; Song, J.W.; Zullo, J.; Lipphardt, M.; Coneh-Gould, L.; Goligorsky, M.S. Endothelial cell dysfunction and glycocalyx-A vicious circle. Matrix Biol. 2018, 71-72, 421-431. [CrossRef] [PubMed] 